Eva Barabas DDs, Elemer K. Zsigmond MD, A. F. Kirkpatrick MD PH D

\title{
The inhibitory effect of esmolol on human plasmacholinesterase
}

Esmolol, a new cardioselective beta adrenergic blocker inhibits plasmacholinesterase activity in vitro. The concentration of esmolol hydrochloride that inhibits by 50 per cent the hydrolysis of $50.0 \mu \mathrm{mol} \cdot \mathrm{L}^{-1}$ benzoylcholine hydrochloride by 1:200 diluted, heparinized pooled plasma of six healthy volunteers at $37^{\circ} \mathrm{C}$ and $240 \mathrm{~nm}$. determined by the ultraviolet spectrophotometric method of Kalow, was 50 umol $\cdot L^{-1}$. Esmolol's primary metabolite, 3-[4-(2-hydroxy-3-(isopropylamino)propoxy)phenyllpropionic acid, had an $l_{50}=190 \mathrm{\mu mol} \cdot \mathrm{L}^{-1}$. The benzoylcholine hydrolysis rates in the plasma of ten patients who received an esmolol infusion of $500 \mu \mathrm{g} \cdot \mathrm{kg}^{-1}$. $\mathrm{min}^{-1}$ for 4 minutes were $58.6 \pm 6.2 \mu \mathrm{mol} \cdot \mathrm{hr}^{-1} \cdot \mathrm{ml}^{-1}$ (mean \pm SE) before and $55.1 \pm 6.6 \mu \mathrm{mol} \cdot \mathrm{hr}^{-1} \cdot \mathrm{ml}^{-1}$ after the infusion. The benzoylcholine hydrolysis rates in the plasma of ten patients who received an esmolol infusion of $500 \mu \mathrm{g} \cdot \mathrm{kg}^{-1} \cdot \mathrm{min}^{-1}$ for two minutes and 200 $\mu \mathrm{g} \cdot \mathrm{kg}^{-1} \cdot \mathrm{min}^{-1}$ for an additional two minues were 70.2 $\pm 8.9 \mu \mathrm{mol} \cdot \mathrm{hr}^{-1} \cdot \mathrm{ml}^{-1}$ before and $69.1 \pm 9.5 \mu \mathrm{mol} \cdot \mathrm{hr}^{-1}$. $\mathrm{ml}^{-1}$ after the infusion. The pre- and post-infusion plasmacholinesterase activities were not significantly different. Since plasmacholinesterase is responsible for the hydrolysis of succinylcholine and that of the ester-type local anaesthetics this lack of in vivo interaction of esmolol with the hydrolysis of these drugs should be further confirmed by experiments with these combinations in man.

\section{Key words}

ENZYMES: plasmacholinesterase, inhibition; NEUROMUSCULAR RELAXANTS: succinylcholine; SYMPATHETIC NERVOUS SYSTEM: sympatholytic agents: esmolol.

From the University of Illinois College of Medicine at Chicago, Department of Anesthesiology, 1740 West Taylor Street, Chicago, Illinois 60612, U.S.A, where correspondence should be addressed to Dr. Zsigmond.
Esmolol is a new, cardioselective ultra-short acting beta adrenergic blocker. The ester linkage in esmolol leads to its rapid hydrolysis in the blood by esterases. Its rapid total body clearance also indicates that the blood esterase activity is the major factor responsible for its rapid breakdown. ${ }^{1,2}$ The enzyme mediating the hydrolysis of esmolol appears to be an esterase that is distinct from plasma cholinesterase..$^{3,4}$

It is well known that succinylcholine and estertype local anaesthetics, e.g., procaine and chloroprocaine, are hydrolyzed by human plasma cholinesterase (PChE, E.C. 3.1.1.8) and their enzymatic hydrolysis is responsible for the termination of their toxicity. 5,6 Drugs that inhibit $\mathrm{PChE}$, therefore, may increase the toxicity of succinylcholine and local anaesthetics. ${ }^{7,8}$

Esmolol and its metabolite may inhibit PChE, based on their chemical structure. Such an inhibition may prolong the duration of neuromuscular block of succinylcholine and increase the toxicity of ester-type local anaesthetics. Therefore this study was undertaken to determine if esmolol and its metabolite possess any inhibitory effect on human plasmacholinesterase.

\section{Methods}

In the first in vitro phase of our study, the source of plasmacholinesterase was freshly obtained heparinized plasma of six healthy volunteers with genetically normal PChE, proven by dibucaine number determinations, who gave written consent after approval of the study by the Institutional Research Review Board. Commercially available benzoylcholine hydrochloride was used in a final concentration of $50.0 \mu \mathrm{M}$. Esmolol hydrochloride, ${ }^{*}$ methyl 3-[4-(2-hydroxy-3-(isopropylamino) propoxy]phenyl propionate hydrochloride, and its metabolic break-

*Obtained in pure crystalline form from American Critical Care, Chicago, IL. 
down product, 3-[4-(2-hydroxy-3-) isopropylamino)propoxy) phenyl]propionic acid (ASL 8123), in concentrations ranging from $1.0 \mu \mathrm{M}$ to $10.0 \mu \mathrm{M}$, were incubated with the plasma diluted in a phosphate buffer for 20 minutes at $37^{\circ} \mathrm{C}$ before the addition of the substrate. The enzymatic hydrolysis rate of benzoylcholine by 1:200 diluted plasma was determined by the method of Kalow ${ }^{10}$ in an ultraviolet spectrophotometer in a phosphate buffer of $\mathrm{pH}=7.4 \pm 0.02$ at $240 \mathrm{~nm}$ and at $37.0 \pm 0.05^{\circ} \mathrm{C}$. The means of duplicate determinations were calculated and presented.

In the second clinical phase of the study the PChE activity of 20 patients who gave valid written consent and who were to undergo surgery requiring endotracheal intubation were studied. All patients were of ASA physical status I-III and were not receiving alpha or beta agonists or antagonists. The patients received $1.5 \mathrm{mg} \cdot \mathrm{kg}^{-1}$ hydroxyzine, 1.5 $\mathrm{mg} \cdot \mathrm{kg}^{-1}$ meperidine and $3.0 \mu \mathrm{g} \cdot \mathrm{kg}^{-1}$ glycopyrrolate IM 90 minutes before anaesthesia and were induced with thiopentone at minute four of the $E$ infusion. Seventy-five-mg doses were given until the disappearance of lid-reflex. Succinylcholine, $1.0 \mathrm{mg} \cdot \mathrm{kg}^{-1}$ IV was used to facilitate tracheal intubation. As soon as relaxation was complete, laryngoscopy was initiated. The mean duration of laryngoscopy approximated 30 seconds in each group. After the completion of intubation, $\mathrm{N}_{2} \mathrm{O}: \mathrm{O}_{2}$ $=3: 2 \mathrm{~L} \cdot \mathrm{min}^{-1}$ with $0.5-1.2$ per cent enflurane was administered. Ten patients with a mean age \pm SE of $50.6 \pm 4.7$ years and weight of $64.8 \pm 4.4 \mathrm{~kg}$ $(M=4, F=5)$ received an esmolol infusion of $50 \mu \mathrm{g} \cdot \mathrm{kg}^{-1} \cdot \mathrm{min}^{-1}$ for four minutes and another ten patients with a mean age $\pm S E$ of $42.2 \pm 4$. 1 years and weight of $75.0 \pm 6.4 \mathrm{~kg}(\mathrm{M}=3, \mathrm{~F}=7) \mathrm{a}$ loading dose by infusion of $500 \mu \mathrm{g} \cdot \mathrm{kg}^{-1} \cdot \mathrm{min}^{-1}$ for two minutes followed by an infusion of 200 $\mu \mathrm{g} \cdot \mathrm{min}^{-1}$ for an additional two minutes prior to anaesthetic induction. The infusion rates utilized have been found effective in attenuating heart rate responses to tracheal intubation in anaesthetized patients. ${ }^{11-13}$ Blood samples for plasmacholinesterase activity were collected in heparinized tubes before and four minutes after the esmolol infusions. The blood samples were separated from the red cells in a refrigerated centrifuge. Plasmacholinesterase activity of each blood sample was determined in duplicate by Kalow's ultraviolet spectrophotometric method.

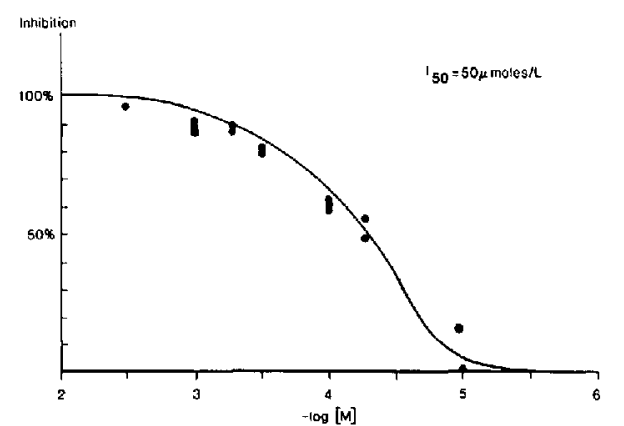

FIGURE 1 I $n$ vitro inhibitory effect of esmolol hydrochloride on human plasma cholinesterase ( $n=6$ ). Each point represents the mean of duplicate determinations.

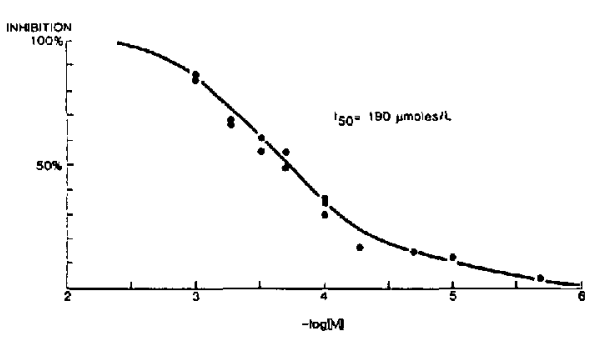

FIGURE 2 In vitro inhibitory effect of the esmolol metabolite on human plasma cholinesterase $(n=6)$. Each point represents the mean of duplicate determinations.

\section{Results}

Esmolol markedly inhibited plasma cholinesterase activity. The concentration that inhibited benzoylcholine hydrolysis to 50 per cent, its $\mathrm{I}_{50}$, was $50 \mu \mathrm{mol} \cdot \mathrm{L}^{-1}$. Plotting the $-\log [\mathrm{M}]$ concentration vs. inhibition, as expected, resulted in an S-shaped curve, shown in Figure 1.

The metabolite of esmolol studied has an $I_{50}$ of $190 \mu \mathrm{mol} \cdot \mathrm{L}^{-1}$, as shown in Figure 2 .

The benzoylcholine hydrolysis rates in the plasma of the ten patients who received an esmolol infusion of $50 \mu \mathrm{g} \cdot \mathrm{kg}^{-1} \cdot \mathrm{min}^{-1}$ for four minutes were $58.6 \pm 6.2 \mu \mathrm{mol} \cdot \mathrm{hr}^{-1} \cdot \mathrm{ml}^{-1}$ (mean $\pm \mathrm{SE}$ ) before and $55.1 \pm 6.6 \mu \mathrm{mol} \cdot \mathrm{hr}^{-1} \cdot \mathrm{ml}^{-1}$ after the infusion. The benzoylcholine hydrolysis rates in the plasma of the ten patients who received esmolol infusion of $500 \mu \mathrm{g} \cdot \mathrm{kg}^{-1} \cdot \mathrm{min}^{-1}$ for two minutes and $200 \mu \mathrm{g}$. 


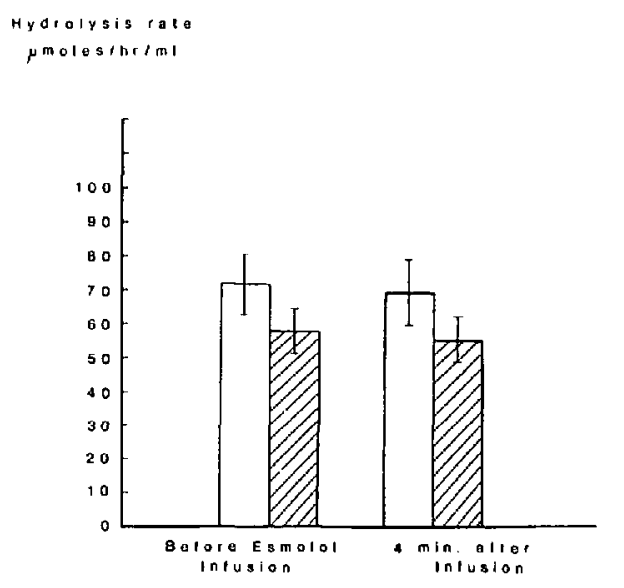

FIGURE 3 Hydrolysis rates of benzoylcholine in vitro by the plasma cholinesterase of patients before and after esmolol infusion.

פ500 $\mu \mathrm{g} \cdot \mathrm{kg}^{-1} \cdot \mathrm{min}^{-1}$ esmolol infusion for four minutes ( $\mathrm{n}=$ 10).

$\square 500 \mu \mathrm{g} \cdot \mathrm{kg}^{-1} \cdot \mathrm{min}^{-1}$ esmolol infusion for two minutes followed by $200 \mu \mathrm{g} \cdot \mathrm{kg}^{-1} \cdot \mathrm{min}^{-1}$ esmolol infusion $(\mathrm{n}=10)$.

$\mathrm{kg}^{-1} \cdot \mathrm{min}^{-1}$ for an additional 2 minutes were 70.2 $\pm 8.9 \mu \mathrm{mol} \cdot \mathrm{hr}^{-1} \cdot \mathrm{ml}^{-1}$ before and $69.1 \pm 9.5 \mu \mathrm{mol}$. $\mathrm{hr}^{-1} \cdot \mathrm{ml}^{-1}$ four minutes after the infusion. Although the initial mean plasmacholinesterase activities differed in the two infusion groups, because of the small number of cases $(\mathrm{N}=10)$, the post-esmolol $\mathrm{PChE}$ activities were not significantly different from the pre-esmolol activities (Figure 3).

\section{Discussion}

It is well known that plasmacholinesterase inhibition or low levels of plasmacholinesterase result in reduction of the hydrolysis of succinylcholine, thereby causing prolongation of its effect. ${ }^{14,15}$ The first laboratory phase of our study showed that esmolol markedly inhibits in vitro human PChE activity as measured by its specific substrate, by Kalow's method. ${ }^{10}$ Therefore, intravenous esmolol infusion might lead to PChE inhibition and to prolongation of the muscle relaxant effect of succinylcholine. Comparison of the $I_{50}$ of esmolol, $50 \mu \mathrm{mol} \cdot \mathrm{L}^{-1}$ with the mean blood level, $3.5 \mu \mathrm{g}$. $\mathrm{ml}^{-1}$ or $10.5 \mu \mathrm{mol} \cdot \mathrm{L}^{-1}$ following infusion of 500 $\mu \mathrm{g} \cdot \mathrm{kg}^{-1} \cdot \mathrm{min}^{-1}$ for four minutes in ten patients reported previously ${ }^{13}$ shows that only a modest inhibition of PChE is likely to occur (10-12 per cent) as can be interpolated from Figure 1 .

In support of this expectation are the data in the second clinical phase of study which showed absence of inhibition of $\mathrm{PChE}$ in ten patients following infusion of esmolol at a rate of $500 \mu \mathrm{g}$. $\mathrm{kg}^{-1} \mathrm{~min}^{-1}$ for four minutes. Consequently, no inhibition was expected, or observed at the lower esmolol infusion rate which is still effective in preventing tachycardia induced by endotracheal intubation. ${ }^{12}$

Although these findings make it unlikely that significant inhibition of PChE activity is caused by esmolol at these infusion rates, interpolation of in vitro hydrolysis to in vivo hydrolysis of various substrates cannot be made because of the 200 -fold dilution of the inhibitor (esmolol) and the influence of the incubation time during the determination of benzoylcholine hydrolysis. ${ }^{16}$ Therefore further studies of the interaction of esmolol with the muscle relaxant effect of succinylcholine and with the toxicity of ester local anaesthetics are needed to determine if an in vivo anticholinesterase effect is present and is of clinical importance.

\section{Conclusion}

A marked inhibition of PChE activity by esmolol was observed in vitro. The metabolite of esmolol studied is one quarter as potent as esmolol as an anticholinesterase. PChE activity was unaltered in the plasma of patients who received an esmolol infusion of $500 \mu \mathrm{g} \cdot \mathrm{kg}^{-1} \cdot \mathrm{min}^{-1}$ for four minutes. Although this latter finding makes unlikely an in vivo interaction of esmolol with succinylcholine and ester-type local anaesthetics, studies in patients with the drug combination should be carried out to determine if such an interaction occurs in man during anaesthesia.

\section{References}

1 Zaroslinski I, Borgman RJ, O'Donnell JP et al. Ultra-short-acting beta-blockers: a proposal for the treatment of the critically ill patient. Life Sciences 1982; 31: 899-907.

2 Gorczynski RJ, Shaffer JE, Lee RL. Pharmacology of ASL-8052, a novel beta-adrenergic receptor antagonist with an ultrashort duration of action. $J$ Cardiovasc Pharmacol 1983; 5: 668-77.

3 Sum CY, Yacobi A, Kartzinel R, Stampfii $H F$, Davis $C S$, Lai CM. Kinetics of esmolol, an ultra-short- 
acting beta blocker, and of its major metabolite. Clin Pharmacol Ther 1983; 34: 427-34.

4 Sum CY, Stampfli H, Lai CM et al. Species differences in the hydrolysis of ester-containing beta blockers by plasma esterases. Proc 33rd National Meeting of the Academy of Pharmaceutical Sciences, San Diego, 1982; 12: 177.

5 Forbath A, Lehmann $H$, Silk E. Prolonged apnea following succinylcholine. Lancet 1953; 2: 1067.

6 Foldes FF, Davis DL, Shanor SP, van Hees GR. Hydrolysis of ester-type local anesthetics and their halogenated analogs by purified plasma cholinesterase. J Am Chem Soc 1955; 77: 5149.

7 Zsigmond EK, Kothary SP, Flynn KB. In vitro inhibitory effect of amide-type local analgesics on normal and atypical human plasma cholinesterase. Regional Anesthesia 1978; 3: 7-9.

8 Zsigmond EK, Eilderton TE. Abnormal reaction to procaine and succinylcholine in a patient with inherited atypical plasmacholinesterase: a case report. Can Anaesth Soc J 1968; 15: 498-500.

9 Zsigmond EK, Eilderton TE. Causes, prevention and treatment of prolonged apnea. J Oral Surgery 1969; 27: 257-61.,

10 Kalow $W$. Hydrolysis of local anesthetics by human serum cholinesterase. J Pharmacol Exp Ther 1952; 104: 122-34.

11 Menkhaus PG, Reves JG, Alvis $J M$ et al. Attenuation of heart rate response to intubation by a new beta-adrenergic blocking drug, esmolol. Anesthesiology 1984; 60: A20.

12 Korenaga GM, Winnie AP, Kirkpatrick AF, Lord $J G$, Barabas E, Zsigmond EK. Effect of esmolol on tachycardia induced by endotracheal intubation. Anesth Analg 1985; 64: 238.

13 Zsigmond EX, Kirkpatrick AF, Barabas E, Korenaga GM, Blazek, GH, Lord JG. Pharmacodynamics and pharmacokinetics of esmolol infusions during thiopental induction and intubation. Anesthesiology 1985; 63: A61.

14 Foldes $F F$. Enzymes in anesthesiology. SpringerVerlag, New York, Heidelberg, Berlin, 1978.

15 Foldes FF, Molloy RE, Zsigmond EK, Zwartz, JA. Hexafluorenium: its anticholinesterase and neuromuscular activity. J Pharmacol Exp Ther 1960; 129: 400 .

16 Foldes $F F$, Smith JC. The interaction of human cholinesterases with anticholinesterases used in the therapy of myasthenia gravis. Ann N.Y. Acad Sci 1966, 135: 287.

\section{Résumé}

L'esmolol, un nouvel agent bloqueur des récepteurs béta inhibe l'activité plasmatique de la cholinesterase in vitro. L'effet inhibiteur de l'esmolol a été déterminé par l'hydrolyse de la benzoylcholine à $50.0 \mu \mathrm{mol} \cdot \mathrm{L}^{-1}$ chez 6 volontaires sains dont les plasmas ont été gardés a $37^{\circ}$ et à $240 \mathrm{~nm}$ par la méthode spectrophotométrique à ultra violer de Kalow. La concentration inhibitrice de 50 pour cent $\left(I_{50}\right)$ de l'esmolol a été trouvée égale à $50 \mu \mathrm{mol} \cdot \mathrm{L}^{-1}$. Le produit de dégradation primaire de l'esmolol, l'acide 3-\{4-(2-hydroxy-3-(isopropylamino) propoxy) phenyl $\}$ propionique avait un $I_{50}=190 \mathrm{\mu mol} \cdot \mathrm{L}^{-1}$. Le taux d'hydrolyse de la benzoylcholine dans le plasma des 10 volontaires ayant reçu une perfusion d'esmolol de 500 $\mu \mathrm{g} \cdot \mathrm{kg}^{-1} \cdot \mathrm{min}^{-1}$ pour quatre minutes était de $58.6 \pm 6.2$ $\mu \mathrm{mol} \cdot \mathrm{hr}^{-1} \cdot \mathrm{ml}^{-1}$ (moyenne $\pm \mathrm{SE}$ ) avant et $55.1 \pm 6.6$ $\mu \mathrm{mol} \cdot \mathrm{hr}^{-1} \cdot \mathrm{ml}^{-1}$ après la perfusion. Le taux d' hydrolyse de la benzoylcholine chez les dix patienss ayant reçu la perfusion d'esmolol de $500 \mu \mathrm{g} \cdot \mathrm{kg}^{-1} \cdot \mathrm{min}^{-1}$ pour deux minutes et $200 \mu \mathrm{g} \cdot \mathrm{kg}^{-1} \cdot \mathrm{min}^{-1}$ pour deux minutes additionnelles était de $70.2 \pm 8.9 \mu \mathrm{mol} \cdot \mathrm{hr}^{-1} \cdot \mathrm{ml}^{-1}$ avant et $69.1 \pm 9.5 \mu \mathrm{mol} \cdot \mathrm{hr}^{-1} \cdot \mathrm{ml}^{-1}$ après la perfusion. L'activité de la cholinestérase plasmatique avant et après perfusion ne présentait aucune différence significative. Etant donné que la cholinestérase plasmatique est responsable de l'hydrolyse de la succinylcholine ainsi que celle des anesthésiques locaux de type ester, labsence d'interaction avec l'esmolol in vivo doit être confirmée par d'autres experiences chez l'homme. 